\title{
Pengaruh Penggunaan Media Pembelajaran CD Tutorial Terhadap Hasil Belajar pada Mata Kuliah Desain Web di AMIK DP Kerinci
}

\author{
Fadlul Amdhi Yul \\ Dosen Universitas Dehasen Bengkulu \\ Fadlulamdhi27@gmail.com
}

\begin{abstract}
ABSTRAK
Keberhasilan belajar dapat dicapai jika mahasiswa berpartisipasi aktif dalam mengikuti proses pembelajaran. Salah satu upaya dalam mengaktifkan siswa yaitu dengan metoda pemebelajaran yang tepat dan sesuai dengan karakteristik mata kuliah yang diajarkan. Salah satu metoda yang dapat mengaktifkan siswa dalam mata pelajaran Desain Web adalah Pembelajaran menggunakan CD Tutorial. Rumusan masalah dalam Penelitian ini adalah untuk melihat perbedaan hasil belajar antara metode pembelajaran Power Point dengan metode pembelajaran CD Tutorial, serta untuk melihat seberapa besar pengaruh metode pembelajaran menggunanakan media CD tutorial dengan Media Power Point. Penelitian ini dilakukan secara kuantitatif dengan jenis penelitian menggunakan quasy eksperimen dengan membandingkan hasil belajar mahasiswa yang belajar langsung menggunakan power point dan belajar menggunakan CD Tutorial. Populasi dalam penelitian ini adalah mahasiswa Semester V AMIK DP Kerinci. Penarikan sampel dilakukan dengan simple sampling dan yang menjadi sampel adalah kelas MI 2 sebagai kelas eksperimen dan kelas $\mathrm{X}_{\mathrm{MI}} 1$ kelas kontrol. Kompetensi Dasar untuk kedua kelas adalah tentang HTML. Data dalam penelitian ini berasal dari hasil belajar mahasiswa di kelas eksperimen dan di kelas kontrol. Data tersebut diolah dengan menggunakan rumus analsis $t$ test.
\end{abstract}

Kata Kunci: Media Pembelajaran CD Tutorial, analisis t test, Hasil belajar mata kuliah disain web.

PENDAHULUAN

Pembelajaran Disain Web yang dilaksanakan selama ini menggunakan metode ceramah, tanya jawab, diskusi demonstrasi dan latihan. Media yang digunakan yaitu berupa media papan tulis, media cetak seperti buku atau jobsheet dan slide power point. Namun proses pembelajaran yang dilakukan belum maksimal dalam meningkatkan 
hasil belajar mahasiswa.

Selain itu, motivasi belajar mahasiswa juga relative rendah. Hal ini di tunjukan oleh kurangnya keterlibatan mahasiswa dalam proses bertanya terhadap materi-materi yang kurang dipahami pada saat perkuliahan dan mengemukakan pendapatnya. Beberapa mahasiswa memilih untuk absen dalam perkuliahan karena tidak menyelasiakan tugas dengan baik.

Media pembelajaran menggunakan Video CD tutorial merupakan salah satu alternatif yang dapat di terapkan guna mendukung kegiatan belajar mengajar serta dapat lebih meningkatkan minat dan motivasi belajar mahasiswa. Setiap mahasiswa dapat dengan mudah mengakses setiap materi dalam suatu mata ajar dengan menggunakan komputer yang tersedia di labor atau mengakses sendiri jika mahasiswa mempunyai komputer/laptop sendiri. Informasi tentang materi yang di ajarkan telah dimasukkan ke dalam format Compact Disc (CD).

Melalui video CD tutorial ini diharapkan mahasiswa dapat lebih mengerti dan memahami tentang mata ajar tertentu dengan cara praktis, terutama mata ajar Disain Web dengan cara belajar lebih efisien.

\section{TUJUAN PENELITIAN}

Tujuan penelitian ini dilakukan untuk mengungkapkan :

1. Perbedaan hasil belajar mahasiswa yang diajar menggunakan Video CD Tutorial dngan mahasiswa yang di ajar dengan media Power Poin pada mata kuliah Disain Web di Akademi Manajemen Informatika dan Komputer Depati Parbo Kerinci.

2. Pengaruh menggunakan Video CD Tutorial terhadap hasil belajar mata kuliah Disain Web pada kemampuan awal di Akademi Manajemen Informatika dan Komputer Depati Parbo Kerinci.

\section{RUMUSAN MASALAH}

Berdasarkan latar belakang di atas dapat dirumuskan masalah-masalah sebagai berikut :

1. Kurangnya sumber belajar yang disediakan sehingga dosen hanya mengandalkan komunikasi secara lisan dengan mahasiswa di lokal, akibatnya banyak waktu terbuang atau tidak efisien dalam proses pembelajaran.

2. Kurangnya motivasi belajar mahasiswa dikarenakan pelajaran tergolong sulit.

3. Minimnya media pembelajaran yang dapat memenuhi kebutuhan belajar mahasiswa secara individual 
sehingga proses pembelajaran yang dilakukan hanya secara klasikal saja.

\section{LANDASAN TEORI}

\subsection{Kajian Teori}

Belajar adalah suatu proses dimana suatu individu berubah prilakunya sebagai akibat dari pengalaman. Belajar didefinisikan sebagai modifikasi atau peneguhan prilaku melalui pengalaman (learning is defined as the modification or strenghening of behaviour through experiencing). Belajar bukan suatu hasil dan bukan pula suatu tujuan tetapi merupakan suatu proses atau aktivitas. Sagala (2009:12) menyatakan bahwa belajar adalah "modification of behaviour through experience and training”, yaitu perubahan tingkah laku dalam pendidikan karena pengalaman dan latihan.

Hasil belajar adalah kemampuan yang diperoleh siswa atau peserta didik setelah melalui kegiatan belajar. Suharsimi (1993:185) mengatakan hasil belajar merupakan suatu hasil pembelajaran yang diperoleh setelah mengikuti proses pembelajaran. Hasil belajar ini biasanya dinyatakan dalam bentuk angka, huruf ataupun kata-kata. Hasil belajar juga menjadi tolak ukur yang dapat digunakan untuk menentukan tingkat keberhasilan siswa dalam menguasai meteri pelajaran.

\subsection{Metode Mengajar}

Cara atau metode mengajar yang digunakan untuk menyampaikan informasi atau pesan menurut Abu dkk (1997:53) adalah metode ceramah, metode tanya jawab dan metode diskusi.

1. Metode ceramah, Yang dimaksud dengan metode ceramah ialah suatu metode di dalam pendidikan dan pengajaran dimana cara menyampaikan pengertianpengertian materi pelajaran kepada anak didik dilaksanakan dengan lisan oleh guru di dalam kelas. Hubungan antara guru dengan anak didik banyak menggunakan bahasa lisan. Peranan guru dan murid berbeda secara jelas, yaitu guru terutama dalam menuturkan dan menerangkan secara aktif, sedangkan murid mendengarkan dan mengikuti secara cermat serta membuat catatan tentang pokok persoalan yang diterangkan oleh guru.

2. Metode tanya jawab,Metode tanya jawab ialah suatu metode di dalam pendidikan dan pengajaran di mana guru bertanya sedangkan muridmurid menjawab tentang bahan materi yang ingin diperolehnya.

3. Metode diskusi,Diskusi adalah suatu $\begin{array}{lrr}\text { kegiatan } & \text { kelompok } & \text { dalam } \\ \text { memecahkan } & \text { masalah } & \text { untuk }\end{array}$ 
mengambil kesimpulan. Diskusi tidak sama dengan berdebat. Diskusi selalu diarahkan kepada pemecahan masalah yang menimbulakan berbagai macam pendapat dan akhirnya diambil suatu kesimpulan yang dapat diterima oleh anggota dalam kelompoknya.

\subsection{Media Pembelajaran}

Dalam proses belajar mengajar berbagai macam media dimanfaatkan. Salah satu kriteria yang sebaiknya digunakan dalam pemeliharaan media adalah dukungan terhadap isi bahan pelajaran dan kemudahan memperolehnya. Menurut Bovee (1997) "Media pembelajaran adalah sebuah alat yang berfungsi untuk menyampaikan pesan pembelajaran”. Dalam hal ini media pembelajaran adalah alat yang digunakan sebagai perantara dalam menyampaikan pesan (konsep atau prinsip) ilmu pengetahuan dari guru kepada mahasiswa selama proses pembelajaran.

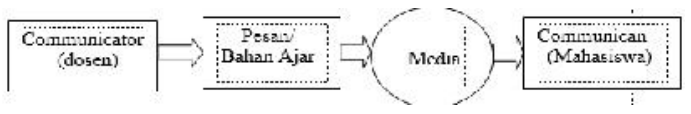

Gambar 1 : Proses Komunikasi dalam

Pembelajaran

\subsection{Media Video CD Tutorial}

Video tutorial adalah adalah rangkaian gambar hidup yang ditayangkan oleh seorang pengajar yang berisi pesan- pesan pembelajaran untuk membantu pemahaman terhadap suatu materi pembelajaran sebagai bimbingan atau bahan pengajaran tambahan kepada sekelompok kecil peserta didik.

Video tutorial/training dapat diproduksi untuk menjelaskan secara detail suatu proses tertentu, cara pengerjaan tugas tertentu, cara latihan, dan lain sebagainya guna memudahkan tugas para trainer/instruktur/guru/dosen/manajer.

Dalam proses produksi video ini, informasi dapat ditampilkan dalam kombinasi berbagai bentuk (shooting video, grafis, animasi, narasi, dan texs), yang memungkinkan informasi tersebut terserap secara optimal oleh para penonton atau mahasiswa. Dalam hal ini video tutorial berupa video atau rekaman langkah-langkah pembuatan web dalam pembelajaran disain web adalah :

a. Compact Disc

b. Multimedia Berbasiskan Komputer

c. Interaktif

d. Human Computer Interaction:HCI (Interaksi Manusia dengan Komputer)

\subsection{Media Power Point}

Microsoft Power Point adalah suatu software yang akan membantu dalam menyusun sebuah media belajar untuk kelas kontrol. Microsoft Power Point membantu sebuah gagasan menjadi lebih 
menarik dan jelas tujuannya jika dipresentasikan karena Microsoft Power Point akan membantu menampilkan slide yang dinamis, termasuk clip art yang menarik, yang semuanya itu mudah ditampilkan di layar infokus. Untuk itulah, penulisan merasa tertarik untuk merancang media pendidikan tersebut dengan menggunakan microsoft power point, yang nantinya akan dibandingkan hasil belajarnya denagn media CD Tutorial.

\subsection{Matakuliah Desain Web}

Disain Web merupakan salah satu mata kuliah keahlian Berkarya, kompetensi dasarnya adalah Mahasiswa mampu mendesain sebuah website, Mahasiswa mampu membuat database, Mahasiswa mampu mengkoneksikan database dan mahasiswa mampu mempublish Website ke jaringan sosial (Internet). Kompetensi ini diperlukan untuk melakukan kegiatan yang berkaitan dengan teknologi informasi yang mana pada saat sekarang ini informasi sangat cepat berkembang melalui media internet maka dibutuhkan sebuah halaman web untuk menyampaikan informasi tersebut.

\section{METODOLOGI PENELITIAN}

Sesuai dengan masalah yang dikemukakan sebelumnya, maka penelitian ini menggunakan pendekatan kuantitatif dengan menggunakan pendekatan pendekatan quasi eksperiment deign. Sugiyono (2012:87) menyebutkan bahwa penelitian quasi eksperiment deign adalah metod penelitian yang digunakan untuk mencapai pengaruh tertentu terhadap yang lain ddalam kondisi terkenali. Penelitian quasi eksperiment deign bertujuan untuk mneliti hubungan sebab dan akibat dengan cara memberikan satu atau lebih kondisi perlakuan kepada kelompok eksperimental, dan membandingkan hasilnya terhadap kelomok kontrol yang tidak menerima perlakuan.

Penelitian ini membagi kelompok menjadi dua yaitu, kelompok eksperimen dan kelompok kontrol. Kedua kelompok hanya dibedakan dalam penerapan metode pembelajaran. Kelompok eksperimen merupakan kelompok yang mendapat perlakuan, yakni dengan penerapan media pembelajaran Video $\mathrm{CD}$ tutorial. Sementara itu kelompok kontrol dalam penelitian ini adalah sebagai pembanding untuk kelompok eksperimen.

\section{Hasil Penelitian dan Pembahasan}

Penelitian ini merupakan penelitian eksperimen yang terbagi dalam 2 kelompok yaitu kelompok eksperimen 
dan kelompok control Pembelajaran yang digunakan pada kelompok eksperimen menggunakan Media pembelajaran video $\mathrm{CD}$ tutorial sedangkan kelompok kontrol menggunakan media pembelajaran power poin atau pengajaran langsung. dalam pengelompokan pengetahuan awal ini mahasiswa diberikan tes dan mahasiswa yang memperoleh nilai tes awal $\geq 50 \%$ tergolong memiliki pengetahuan awal tinggi, sedangkan mahasiswa yang memperoleh nilai tes awal $\leq 49 \%$ tergolong memiliki pengetahuan awal rendah.

Deskripsi data penelitian tes kemampuan awal mahasiswa pada mata kuliah desain web terdiri dari dua keloompok, yaitu data nilai hasil tes kempuan awal mahasiswa kelompok eksperimen dan data nilai hasil tes kemampuan mahasiswa kelompok kontrol. Data nilai tes kemampuan awal mahasiswa tersebut dibagi lagi menjadi dua bagian yaitu, kelompok mahasiswa yang berkemampuan awal tinggi dan kelompok mahasiswa berkemampuan awal rendah.

Hasil analisa data nilai tes kemampuan awal mahasiswa pada mata kuliah desain web, dapat disimpulkan pada Tabel 1 berikut :

Tabel 1 : Hasil analisa data nilai tes kemampuan

\begin{tabular}{l|l|l|l}
\hline \multicolumn{2}{c|}{$\begin{array}{c}\text { PENGETAHUAN AWAL } \\
\text { KELAS KONTROL }\end{array}$} & \multicolumn{2}{c}{$\begin{array}{c}\text { PENGETAHUAN AWAL } \\
\text { KELAS EKSPERIMEN }\end{array}$} \\
\hline TINGGI & 3 Orang & TINGGI & 5 Orang \\
\hline RENDAH & 22 Orang & RENDAH & 22 rang \\
\end{tabular}

Kedua kelompok pengetahuan awal tinggi dan rendah tersebut memilik perbedaan, maka dalam penelitian ini penulis hanya mengambil kemampuan awal yang sama yaitu kemampuan awal rendah dimana kelas kontrol sebanyak 22 orang mahasiswa dan kelas eksperimen sebanyak 22 orang mahasiswa.

\section{Analisis Deskriptif}

Setelah dilakukan penelitian kedua kelas yaitu kelas eksperimen dan kelas kontrol. Dimana data yang diolah pada penelitian ini adalah data tes akhir penelitian dengan perlakukan berbeda pada setiap kelas. Pada tes akhir digunakan 20 soal diperoleh dari soal test uji coba sebanyak 27 soal uji coba yang sebelumnya telah dilakukan uji validitas soal, uji reliabilitas soal, indeks kesukaran dan daya beda soal. Pada kelas eksperimen tes akhir diikuti oleh 22 mahasiswa sedangkan pada kelas kontrol diikuti oleh 22 orang mahasiswa. Berikut hasil penelitian dan perhitungan deskriktif pada kelas kontrol dan kelas kelas eksperimen terlihat pada tabel 2 


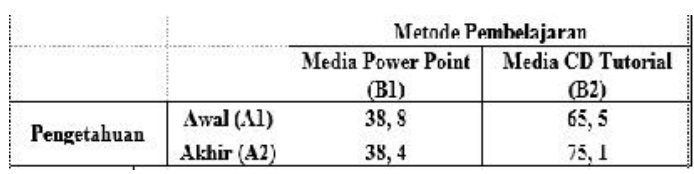

Berikut ini merupakan data hasil penelitian yang diolah dengan SPSS 20 :

\begin{tabular}{|c|c|c|c|}
\hline \multicolumn{4}{|c|}{ Statistics } \\
\hline & & Kclas_Kontrol & Kolas_Eksperimon \\
\hline \multirow{2}{*}{$\mathrm{N}$} & Valid & 22 & 22 \\
\hline & Missing & 0 & $n$ \\
\hline \multicolumn{2}{|c|}{ Mcan } & 65.8182 & 75.0900 \\
\hline \multicolumn{2}{|c|}{ Median } & 61.5000 & 15.5000 \\
\hline \multicolumn{2}{|c|}{ Mode } & 00.00 & $60.00^{\circ}$ \\
\hline \multicolumn{2}{|c|}{ Stc. Devafion } & 10.05526 & 10.18360 \\
\hline \multicolumn{2}{|c|}{ Varlance } & 101.108 & 103.706 \\
\hline \multicolumn{2}{|c|}{ Range } & 44.00 & 34.00 \\
\hline \multicolumn{2}{|c|}{ Minımum } & 40.00 & 36.00 \\
\hline \multicolumn{2}{|c|}{ Maximum } & 84.00 & 90.00 \\
\hline \multicolumn{2}{|c|}{ Sum } & 1448.00 & 1652.00 \\
\hline
\end{tabular}

Dari Tabel 2 dapat dilihat bahwa nilai rata-rata kelas eksperimen lebih tinggi dibandingkan dengan kelas kontrol yaitu rata-rata kelas eksperimen 75,09 sedangkan kelas kontrol 65,81. Selain itu data nilai mahasiswa juga menyebar, dapat dilihat pada Tabel 4.6 berikut:

\section{Tabel 4 kelas interval kelas Kontrol}

\begin{tabular}{c|c|c}
\hline Interval & freluensi & Persentass $(\%)$ \\
\hline $40-48$ & 1 & 4,55 \\
\hline $49-57$ & 4 & 9,09 \\
\hline $58-66$ & 5 & 40,91 \\
\hline $67-75$ & 8 & 27,27 \\
\hline $76-84$ & 7 & 18,18 \\
\hline unlch & 28 & 100
\end{tabular}

pada tabel 4 terlihat bahwa distribusi frekuensi nilai pada sampel eksperimen relative menyebar. Dan dari gambar 2 juga dapat dilihat:

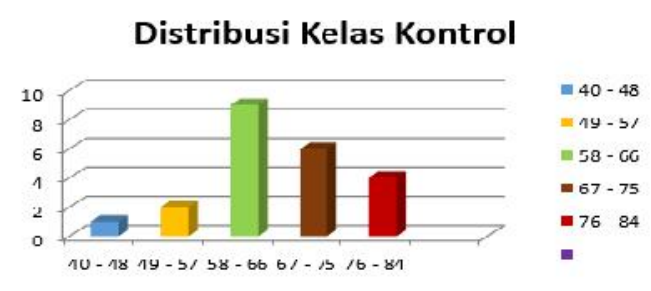

\section{Gambar 2. Output Analisa Frekuensi Kelas Kontrol}

Dari gambar 2 pada histogram terlihat bahwa kurva normal membentuk seperti gunung melenceng ke kanan berarti data yang diperoleh positif, sehingga dapat dikatakan data terdistribusi normal.

\section{Tabel 5 kelas interval kelas}

\section{Eksperimen}

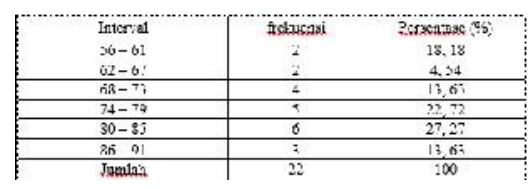

Pada tabel 10 terlihat bahwa distribusi frekuensi nilai pada sampel eksperimen relative menyebar. Dan dari gambar 3 juga dapat dilihat:

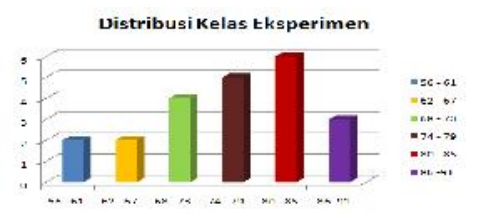

Gambar 3 Output Hasil Analisa

Frekuensi Kelas Eksperimen

Dari gambar 3 pada histogram terlihat bahwa kurva normal membentuk seperti gunung melenceng ke kanan 
berarti data yang diperoleh positif, sehingga dapat dikatakan data terdistribusi normal.

\section{B. Prasyarat Analisis}

\section{Uji normalitas}

Tabel 11 menunjukan normalitas data. Normalitas diolah dengan menggunakan SPSS 20 dengan uji normalitas Kolomogorov Smirnov.

\section{Tabel 6. uji normalitas}

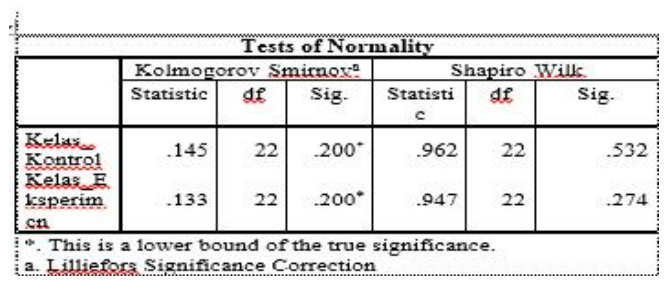

Dilihat dari Tabel 11 bahwa signifikan kelas eksperimen dan kelas kontrol adalah 0, 200 , hal ini menandakan nilai signifikan 0,200>0,05 maka nilai kelas eksperimen dan kelas kontrol berdistribusi normal. Jadi dapat disimpulkan bahwa sampel berasal dari populasi yang terdistribusi normal. Pada gambar 4 berikut dapat juga dilihat bahwa data berdistribusi normal :

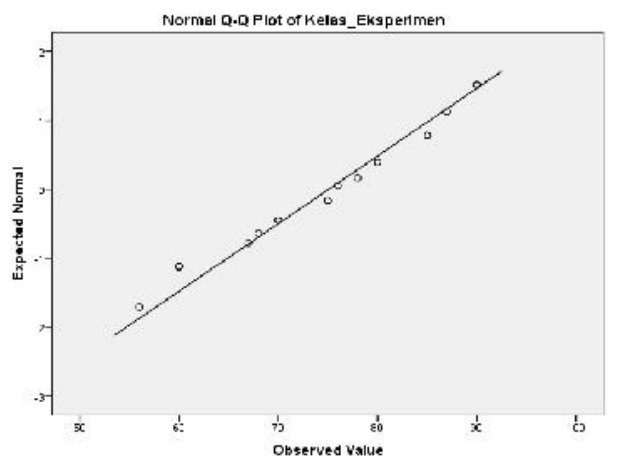

Gambar 4 Q Q plot kelas eksperimen

Pada gambar 4 terlihat bahwa penyebaran frekuensi terletak pada garis normal. Itu artinya data berdistribusi normal.

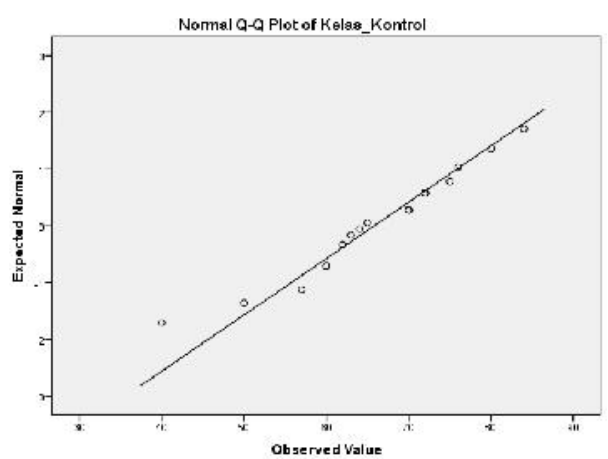

\section{Gambar 5 Q Q Plot Kelas Kontrol}

Pada gambar 4 terlihat bahwa penyebaran frekuensi terletak pada garis normal atau hampir mendekati garis normal. Itu artinya data berdistribusi normal.(lampiran 18)

\section{Uji homogenitas}

Uji homogenitas bertujuan untuk melihat apakah kedua data kelompok data berasal dari populasi yang memiliki 
varians yang hampir sama. Uji homogenitas menggunakan SPSS 20 dengan One Way Anova.

Tabel 7. Uji Homogentas

Test of Homogeneity of

Variances

Kelas_Kontrol

\begin{tabular}{|c|r|r|r|}
\hline $\begin{array}{c}\text { Levene } \\
\text { Statistic }\end{array}$ & df1 & $\begin{array}{c}\text { df } \\
2\end{array}$ & Sig. \\
\hline 2.773 & 5 & 10 & .20 \\
\hline
\end{tabular}

Probabilitas untuk levene test sig. adalah $0,202>0,05$, itu artinya tidak terdapat perbedaan varians antara kelas kontrol dan kelas eksperimen pada variable score atau nilai. Ini menunjukkan bahwa variable nilai homogen.

\section{PEMBAHASAN}

Rata-rata hasil belajar kelompok eksperimen dengan media pembelajaran Video CD Tutorial sebesar 75,83 dan untuk kelompok kontrol sebesar 70,00. Sehingga rata-rata hasil belajar mahasiswa dengan media pembelajaran CD Tutorial lebih baik daripada pembelajaran dengan menggunakan media Power Point.

Salah satu faktor yang mempengaruhi hasil belajar mahasiswa adalah faktor eksternal diantaranya kemampuan dosen untuk memilih media pembelajaran yang digunakan dalam kegiatan belajar mengajar. Dalam proses pembelajaran tidak semua mahasiswa atau peserta didik dapat menangkap apa yang disampaikan desen dengan baik. Untuk itu diperlukan suatu media yang digunakan sebagai alat bantu untuk memperlancar proses belajar mengajar.

Pembelajaran pada kelompok eksperimen secara nyata lebih baik daripada kelompok kontrol karena keaktifan mahasiswa pada kelompok eksperimen lebih tinggi, di samping itu karena adanya Tutorial yang membimbing secara langsung kpeada mahasiswa. Pembelajaran ini mampu menciptakan dampak yang baik terhadap hasil belajar mahasiswa. Dengan adanya Video Tutorial, bagi mahasiswa yang merasa mampu akan menciptakan kreatifitas yang baik dan dapat memberikan masukan yang berarti bagi teman lainnya.

Pada kelas kontrol dosen menjelaskan dengan bantuan media power point, peran mahasiswa akan mendengarkan apa yang disanpaikan dosen sehingga membuat mahasiswa akan merasa jenuh dan kurang bersemangat, dan metode yang digunakan akan menjadi kurang efektif. 


\section{KESIMPULAN}

Setelah melakukan penelitian ini dan hasil analisis terhadap hipotesis penelitian dapat disimpulkan :

1. Terdapat perbedaan yang cukup signifikan terhadap hasil belajar mahasiswa yang menggunakan media $\mathrm{CD}$ tutorial dengan yang menggunakan media Power Point. Dimana hasil belajar yang menggunakan media $\mathrm{CD}$ tutorial lebih tinggi dibandingkan dengan yang menggunakan power point.

2. Pembelajaran menggunakan media CD tutorial berpengaruh terhadap hasil belajar mata kuliah desain web semester V kelas MI 1 dan MI 2 AMIK Depati Parbo Kerinci yaitu pada kelas ekperimen dengan menggunakan media CD Tutorial berpengaruh sebanyak 94, $84 \%$ dari pengetahuan awal sedangkan pada kelas kontrol yang menggunakan media power point berpengaruh sebesar 69, $58 \%$. Dapat disimpulkan Media CD tutorial memberikan sumbangan atau peningkatan hasil belajar yang sangat banyak di bandingkan media power point.

3. Pembelajaran menggunakan media CD Tutorial dapat menumbuhkan kreatifitas dan motivasi mahasiswa untuk belajar, sehingga bisa meningkat hasil belajar mahasiswa.

\section{DAFTAR PUSTAKA}

Ahmad, Abu. Joko Tri Prasetya.1997. SBM (Strategi Belajar Mengajar). Untuk Fakultas Tarbiyah Komponen MKDK. Bandung:Pustaka Setia.

Ahmad Rohani. 1997. Media Instructional Educatif. Jakarta: Rineka Cipta

Arikunto, Suharsimi.2006. Prosedur Penelitian : Suatu Pendekatan Praktek. Jakarta :PT Rineka Cipta. Ahmadi, dkk. 2011. Pembelajaran akselerasi. Jakarta : PT.Prestasi Pustakaraya.

Arsyad, Azhar. 2007. Media Pembelajaran. Jakarta : PT Raja Grafindo Persada

Asyhar, Rayandra. 2011. Kreatif Mengembangkan Media Pembelajaran. Jakarta: Gaung Persada Press.

Depdiknas. (2003). Undang-undang RI Nomor 20, Tahun 2003, Tentang Sistem Pendidikan Nasional. Hakim. 2000. Belajar Secara Efektif. Jakarta. Puspa Swara

Heweet, dkk. 2004. Human Computer Interaction. ACM SIGCHI.

Hanson, J. (1987). Understanding Video Applications, Impact, and theory. California:SAGE Publications, Inc. 
Kusumaningrum, Indrati. 2007. Modul Proses Pembelajaran. Panitia sertifikasi Guru: Universitas Negeri Padang.

Mulyasa.2007.Kurikulum Tingkat Satuan

Pendidikan.Bandung.Rosda

Karya.

,Moh. 2003. Metode Penelitian. Jakarta:Ghalia Indonesia.

Program Magister (S2) Pendidikan Teknolgi dan Kejuruan (2011). Pedoman Penusunan Tesis.

Ramayulis . 2004. Strategi Belajar Mengajar. Jakarta: Rineka Cipta

Sagala, Syaiful.2003.Konsep dan Makna Pembelajaran.

Bandung:CV.Alfabeta

Sudijono, Anas.1995. Pengantar Evaluasi Pendidikan. Jakarta: Gravindo.

Sugiyono, 2012. Metode Penelitian Kuantitatif Kualitatif dengan $R$ \& D. Bandung : AlfabetA

Sumadi Suryabrata. 2004. Psikologi Pendidikan. Jakarta: PT. Raja Grafindo Persada.

Udin S. Winataputra, dkk. 2001. Strategi Belajar Mengajar. Jakarta: Universitas Terbuka.

Wina Sanjaya. 2005. Pembelajaran dalam Implementasi Kurikulum Berbasis Kompetensi . Jakarta : Kencana Prenada Media Group
Wicaksana Jonet. 2006. Rahasia Dibalik Kepingan CD. CD Ilmu Komputer edis 2006.

Winastwan Gora S. 2007. Produksi CD Mutimedia Interaktif. http://www.rumahmedia.com/.

Yusuf Hadi Miarson. 2004. Menyamai Benih Teknologi Pendidikan. Jakarta. Kencana Media Group 